\title{
Break or Continuity? Friedrich Engels and the Critique of Digital Surveillance
}

\author{
Dimitrios Kivotidis
}

University of East London, London, UK, d.kivotidis@uel.ac.uk

\begin{abstract}
This paper is a contribution to the argument that Engels's work remains topical and may provide us with the analytical tools necessary to approach contemporary manifestations of capitalist contradictions. Based on Engels's work on political economy (with emphasis on his contribution to the labour theory of value and the articulation of the law on the tendency of the rate of profit to fall) it will critically review the concept of "surveillance capitalism" as developed by Shoshana Zuboff, in order to explain central aspects of the process of digital surveillance. In particular, it will criticise the view expressed by Zuboff that surveillance capitalism constitutes a break with capitalism's past and can be tamed through an enhancement of democratic accountability and regulation. Marxist contributions to the critique of digital surveillance have already approached this phenomenon in a many-sided manner. This paper builds upon these contributions and suggests that the exponential growth of digital platforms can be explained as a direct result of the development of capitalist contradictions, especially the contradiction between productive forces and relations of production as expressed in the law of the falling rate of profit.
\end{abstract}

Keywords: Friedrich Engels, digital surveillance, surveillance capitalism, turnover time, rate of profit

\section{Introduction}

This year marks two hundred years since the birth of Friedrich Engels, one of the Dioscuri of Marxist thought. By the time of his death, seventy-five years later, Engels had contributed greatly to the scientific analysis of social processes as well as to the growth and theoretical equipment of the international working-class movement. However, for the greater part of the period since his death, Engels's work has received scorn and has been subject to waves of attacks - often from within "leftist" or "Marxist" currents. These attacks focus on various aspects of his work (on the dialectics, on political economy, on the state, etc.) and for the most part aim to dissociate Engels from Marx, claiming that the former distorted the work of the latter. In doing so they aim to discredit the revolutionary and scientific credentials of Marxist thought.

Indeed, one of the main characteristics of Engels's - as well as Marx's - work is its commitment to base the revolutionary critique of capitalism on firm and rigorous scientific analyses and not just on moral condemnation. This paper claims that Marx and Engels's analysis of capitalism is still appropriate and necessary to analyse contemporary phenomena and processes, such as the process of digitalisation of the public and private sphere.

This paper will critically review the concept of "surveillance capitalism" as developed by Shoshana Zuboff in order to explain central aspects of the process of digitalisation. In particular, based on Engels's work on political economy (with emphasis on his contribution to the labour theory of value and the articulation of the law on the tendency of the rate of profit to fall) it will criticise the view expressed by Zuboff that surveillance capitalism constitutes a break with capitalism's past and can be tamed 
through an enhancement of democratic accountability and regulation. Zuboff's analysis fails to comprehensively grasp the totality of implications of the process of digitalisation, as she disregards the issue of exploitation and the centrality of the contradiction between productive forces and productive relations.

Despite several attacks on Engels's role in the publication of Capital, it is well established that his work was essential for the rigorous application of Marxist analysis to various fields (Gould 1977; Waitzkin 1983; Lewontin and Levins 1985). Engels was a pioneer in the development of the dialectical materialist analysis of social processes and phenomena, central tenets of which, such as approaching a social formation as a totality and ascribing centrality to the role of productive relations, are crucial for grasping the social effects of the processes of automation and digitalisation. Capitalist productive relations determine how the forces of production are put to use and the laws of motion of capitalist economy necessitate the processes of exploitation and realisation of surplus value, which determine the operation of phenomena that Zuboff describes under the term "surveillance capitalism".

This paper argues that Engels's work on political economy, focusing on the contradiction between productive forces and relations of production, is key for grasping that phenomena and processes described under the term "digital" or "surveillance capitalism" do not constitute a break with capitalism's past, but result from the historical development of tendencies inherent in the laws of motion of the capitalist mode of production. To do so it draws attention to one particular aspect of Engels's contribution: the effect of turnover time on profitability. This aspect of the Marxist critique of political economy has not been adequately developed. The importance of turnover time reduction for understanding the development of "surveillance capitalism" is hinted at by certain Marxist thinkers. It is this paper's modest contribution, celebrating the thought of one of the founders of Marxism, to explicitly articulate the importance of this aspect of Engels's analysis of capitalism for the understanding of the process of digitalisation and invite further research from a Marxist standpoint on this issue.

On this basis the paper is structured in three sections. The first section synoptically presents Engels's contribution to the critique of political economy, focusing on the theory of crisis and the contradiction between productive forces and relations of production. The section concludes with a presentation of Engels's elaboration on the relationship between turnover time and profitability. The next section critically discusses Zuboff's concept of "surveillance capitalism" from a Marxist standpoint. In particular, using Engels's methodological approach of the capitalist social formation as a totality with focus on the sphere of production, we shall criticise Zuboff's claim that "surveillance capitalism" constitutes "a break with capitalism's past" or "a coup from above", arguing that it is rather a result of the developing contradiction between productive forces and capitalist relations of production. The last section will present alternative views on digital surveillance from a Marxist standpoint and examine how exactly they contribute to a more comprehensive analysis of these processes and phenomena, as well as how Engels's work has influenced and can further influence these approaches.

\section{Engels on Political Economy}

\subsection{Attacks on Engels's Work}

This paper argues that Engels's work remains topical and contains elements whose implications and significance for analysing contemporary phenomena and processes are not fully explored. Of course this view contradicts the waves of attacks that his 
work has been subjected to for many decades. Therefore, a synoptic review of the main points of these attacks is pertinent here in order to highlight our claim. It has been argued that an "anti-Engels outlook" emerged as defining characteristic of the Western academic left (Foster 2017). The axiomatic opposition of "Western Marxism" to Engels's work can be summed up in the following points.

The first concerns Marxist epistemology and method of analysis, i.e. dialectical materialism. Engels is accused of misrepresenting Marx's dialectics as a mechanistically objective method and of trying to imprison Marx's free critical spirit in the cage of a standardised system (McLellan 1977; Carver 1984). More specifically, Engels is considered responsible for introducing positivism into Marxism, eventually leading to the positivism of the Second and Third Internationals and Stalinism (McLellan 1977). Directly linked to this is the accusation that Engels committed the sin of promoting "quasi-Hegelianism, materialism, [...] and dialectics" which are "miles away from Marx's painstaking eclecticism" (Carver 1984, 278).

This point echoes the post-war Western philosophical axiomatic opposition to the objectivity of dialectics, i.e. to the objective existence of contradiction in natural and social phenomena and processes that dialectical logic approaches and analyses (llyenkov 2020; Losurdo 2004). It also introduces the opposition between Marx, a liberal and refined intellectual, and Engels, a coarse populariser. Pitting Marx against Engels ultimately serves a similar purpose as pitting "young Marx" against the "old Marx" (Althusser 2006), or pitting "young Lenin" against "old Lenin" (Anderson 1995), or pitting Lenin against Marx, and so on and so forth. This formal opposition betrays the rejection of and attack on the revolutionary elements and scientific credentials of Marxist analysis. It has, therefore, not just philological but also theoretical and political implications.

Another current, which has directed their attacks on Engels's work on political economy, is led by the Neue Marx Lektüre (New Reading of Marx) authors (Mavroudeas 2020). According to this current, Engels distorted Capital with unwarranted interventions by misrepresenting it as a finished work when in reality it was just an incomplete research project (Heinrich 1996/97). The crux of this critique is the attack on Marx's theory of economic crises. Engels is accused of ascribing to Marx a theory of economic crisis based on the Law of the Falling Rate of Profit (LFRP), whereas the latter supposedly stopped adhering to this law from some point onwards (Heinrich 2016).

The political implications are palpable here as well. Whether Marx had developed a coherent theory of crisis is a matter of intense theoretical and political debate (Heinrich 2013; Roberts 2013). The most dominant interpretations of crises of capitalist production consider them as due to "underconsumption", i.e. a lack of spending by workers who do not have enough to spend, or due to "disproportion", i.e. the anarchy of capitalist production whereby production in various sectors can get out of line with others and can outstrip demand, or due to the lack of profitability in an economic system that depends on profit being made for private owners in order for investment and production to take place (Roberts 2015).

The political implication of the first two interpretations is that capitalist crises are susceptible to Keynesian solutions of full employment and regulation, i.e. capitalism can be saved from itself through reforms. According to the third interpretation crises in capitalism are inevitable due to contradictory nature of the capitalist mode of production. This of course does not prove that the supersession of capitalism is inevitable, but shows the instability of the capitalist mode of production which tends towards 
constant immiseration of the popular strata. The counter-acting factors reproduce capitalism at the cost of dehumanisation.

\subsection{Engels's Critique of Capitalist Contradictions}

We shall now turn to the main elements of Engels's work on political economy, in order to show how his and Marx's analyses approached the contradictions of the capitalist mode of production and highlight their insights which are relevant for the analysis of contemporary processes and phenomena. To begin with, Engels stressed the point that a critique of the capitalist mode of production cannot be reduced to moral condemnation. The task of a socialist critique of capitalism is the scientific exposition of its laws in order to demonstrate "that this mode of production, by virtue of its own development, drives towards the point at which it makes itself impossible" (Engels $1878,138-139)$. In other words, the essence of the scientific analysis of capitalism is the exposition of the contradictions inherent in this mode of production.

These contradictions are generally expressed in the form of the contradiction between productive forces and relations of production. According to Engels, the socialist critique of capitalism is tasked with proving that capitalist relations of production hinder the development of productive forces. One can, for instance, consider how the technological developments of automation and digitalisation in capitalism tend to result in unemployment and a quantitative and qualitative devaluation of labour power.

Engels's materialist approach points to the primacy of productive relations in order to understand and analyse phenomena in the sphere of distribution, which are eventually perceived as phenomena of injustice: "the manner in which wealth is distributed and society divided into classes or orders, is dependent upon what is produced, how it is produced, and how the products are exchanged" (Engels 1878, 135136; Engels 1880, 306). Nevertheless, the processes and relations of distribution are "not a merely passive result of production and exchange"; in its turn distribution reacts upon both of these (Engels 1878, 137). What is more, differences in distribution manifest themselves as class differences: "Society divides into classes; the privileged and the dispossessed, the exploiters and the exploited, the rulers and the ruled" (Engels 1878, 136-137). These class divisions determine the growing perception that "existing social institutions are unreasonable and unjust" (Engels 1880, 306). However, this "is only proof that in the modes of production and exchange changes have silently taken place, with which the social order, adapted to earlier economic conditions, is no longer in keeping" (Engels 1880, 306).

It follows from the above that, according to Engels, capitalist social relations have to be approached as a totality whose different aspects are in constant interaction with each other. Additionally, we can also deduce the materialist principle according to which the perception of injustice is proof of the contradiction between productive forces and relations of production. The dialectics of capitalism is an objective dialectics: "the conflict between productive forces and modes of production [...] exists, in fact, objectively, outside us, independently of the will and actions even of the men that have brought it on" (Engels 1880, 307).

The contradiction between productive forces and relations of production manifests itself in different forms, such as the contradiction between the concentration and socialisation of the productive process and the individual ownership of means of production. This contradiction, which "gives to the new mode of production its capitalistic character" and "contains the germ of the whole of the social antagonisms of today" (Engels 1880, 310), manifests itself also as "the antagonism of proletariat and bourgeoisie" (Engels 1880, 311). Furthermore, it "presents itself as an antagonism be- 
tween the organisation of production in the individual workshop and the anarchy of production in society generally" (Engels 1880, 313). This anarchy in production is responsible for the transformation of the "great majority of men into proletarians", as well as for the transformation of machinery from potential liberator of humanity from the shackles of necessity into "the most powerful weapon in the war of capital against the working-class" which constantly tears "the means of subsistence out of the hands of the labourer" (Engels 1880, 315).

Last but not least, Engels sketches out the contradiction between "the enormous expansive force of industry" (which is driven by the need for valorisation and expanded reproduction of capital) and the resistance offered "by consumption, by sales, by the markets for the products of modern industry", the extension of which "cannot keep pace with the extension of production" (Engels 1880, 315).

\subsection{The Law of the Falling Rate of Profit}

Another manifestation of the contradiction between productive forces and productive relations, albeit one that Engels does not explore in his individual works but one that his work was crucial in articulating, is the law of the tendency of the rate of profit to fall (LFRP). According to this law, the value of the means of production (machinery, offices and other equipment) will, over time, rise relative to the value of labour power (the cost of employing a labour force) (Roberts 2015). Marx called this process the rising organic composition of capital (Marx 1894, 317-338). However, since value (and profit) is only created by labour power, the value produced by labour power will, over time, decline relative to the cost of investing in means of production and labour power. In other words, the ratio of surplus value to the total capital (i.e. the sum of constant capital corresponding to the value of raw materials and means of production and variable capital corresponding to the value of labour power) advanced by the capitalist will tend to diminish. Consequently the rate of profit will tend to fall (Roberts 2015).

It has to be noted that the law appears as a tendency because of the operation of various countertendencies. These include the intensification of exploitation of labour power, the depression of wages below the value of labour power, the cheapening of the value of constant capital, foreign trade, etc. (Marx 1894, 338-348). These countertendencies do not abolish the law but they cause it to "operate more as a tendency, i.e. as a law whose absolute realisation is held up, delayed, and weakened, by counteracting factors" (Marx 1894, 335). Nevertheless, Marx seemed to be certain that the rate of profit would fall as a result of the development of productivity (Moseley 2018, 103) and thus that the capitalist productive relations would become the real barrier for the development of productive forces (Marx 1857/1858, 749): "The true barrier to capitalist production is capital itself' (Marx 1894, 358).

In a letter to Engels in 1868, Marx referred to the law as "one of the greatest triumphs over the pons asini of all previous political economy" (Marx 1868, 24). This says a lot about the explanatory value of the LFRP. For instance, a compelling argument has been made that the cause of recurring and regular economic crises or slumps in output, investment, and employment in modern economies can be found in the LFRP (Carchedi and Roberts 2018). One could go even further than that and advance the hypothesis that the LFRP is key to explaining most contemporary developments of the capitalist mode of production in its imperialist stage, i.e. off-shoring, relative de-industrialisation, financialisation, digitalisation and automation, neoliberalism and labour deregulation, etc. 
This is not the place to develop, let alone test, such a multifaceted hypothesis, but it is of direct interest to us, on the contrary, to discuss Engels's role in the discovery and articulation of this law. The discovery of the law itself is of course attributed to Marx. However, since the law is presented in the third volume of Capital, which was edited by Engels and published after Marx's death, Engels's contribution to its articulation cannot be denied. In general, the streamlining of Marx's notebooks into the second and third volumes of Capital has been described as an "unmitigated feat" and "major contribution" of Engels in political economy (Mavroudeas 2020). Regarding the third volume in particular, it has been argued that Engels's editing makes Marx's manuscript look much more complete and organised than it actually was, but he mostly did not change the content of what Marx wrote (Moseley 2015, 41).

As far as the LFRP is concerned, the role of Engels is central to the debate about Marx's relation to the law itself. As we saw above, it is argued that Marx had stopped adhering to the law and Engels is accused of making "far too much of Marx's law" and distorting Marx's view on this (Heinrich 2016; Roberts 2015). This view is refuted by the aforementioned letter to Engels, but also by a close examination of Engels's work and editorial changes on Marx's writing on the law. On this basis, it is argued that Engels did not overemphasise the importance of the law. On the contrary, he actually made it appear that Marx balances the countertendencies in equal measure with the law as such, when the original order of the text reemphasises the law after talking about counter-influences (Seigel 1978, 339). Engels's interventions did not distort Marx's drafts but rather made them appear sharper and thus more useful for contemporary political and societal debate (Roth and Moseley 2002, 11).

We conclude this brief exposition of Engels's valuable contribution to the critique of political economy with reference to what has been characterised as the hidden gem of his contribution, i.e. his focus on the effect of the turnover of capital in relation to profitability (Mavroudeas 2020). This is explored in Chapter IV of the third Volume of Capital, which is now recognised as having been written exclusively by Engels (Moseley 2015, 13). According to Engels then, the quantity of produced surplus value is augmented by reductions in the period of turnover, because the shorter the period of turnover the smaller the portion of capital that sits idly and the larger the appropriated surplus value, all other conditions remaining the same (Marx 1894, 163). "But since the rate of profit simply expresses the ratio of the mass of surplus value produced to the total capital engaged in producing it, it is evident that any reduction of this kind raises the rate of profit as well" (Marx 1894, 163). It follows then that any methods which contribute to a reduction in turnover time can be considered factors that counteract the LFRP. This is an important point for the argument developed in the following sections.

Since the cycle of accumulation consists of the production process and the circulation process, it follows that for the turnover time to be reduced the cycle of production and/or the cycle of circulation have to be accelerated. According to Engels, the reduction of production time is predominantly achieved through higher labour productivity, whereas the reduction of circulation time is predominantly achieved through improved communications. Regarding the latter, Engels refers to eighteenth-century developments (railway, steamboat line, telegraph wires, Suez Canal) that radically reduced the time of circulation (Marx 1894, 164). This paper argues that following the same logic we can understand recent developments, such as digital surveillance, targeted advertising, data mining, etc., as serving the purpose of reducing turnover time and constituting factors that counter the LFRP. 


\section{Zuboff's Surveillance Capitalism}

Let us now turn to one of the most widely read and highly praised analyses of the process of digitalisation, i.e. Shoshanna Zuboff's work on surveillance capitalism. Zuboff provides us with several definitions of surveillance capitalism. She speaks of "a new economic order that claims human experience as free raw material for hidden commercial practices of extraction, prediction, and sales"; "a parasitic economic logic in which the production of goods and services is subordinated to a new global architecture of behavioural modification"; "a rogue mutation of capitalism marked by concentrations of wealth, knowledge, and power unprecedented in human history"; "the origin of a new instrumentarian power that [...] presents startling challenges to market democracy"; "an expropriation of critical human rights that is best understood as a coup from above: an overthrow of the people's sovereignty" (Zuboff 2019, v).

Several points can be raised regarding this extensive definition of surveillance capitalism. First, the vague signifiers "new economic order", "new economic logic", "origin of a new instrumentarian power" attest to the difficulty of defining this concept. It is hard to define what makes "surveillance capitalism" a distinct form of capitalism. Furthermore, Zuboff's attempts at defining "surveillance capitalism" as capitalism's rogue mutation betray the author's choice of a Keynesian framework which focuses on the concentration of wealth and the ensuing wealth inequalities, and not on the issue of exploitation. In other words, its one-sided focus on distributive relations is the exact opposite to Engels's approach of capitalist social relations as a totality, where productive relations play a predominant role.

Nevertheless, the reference to the parasitic nature of surveillance capitalism is framed in terms of a pseudo-Marxist argument. Surveillance capitalism's parasitic nature "revives Karl Marx's old image of capitalism as a vampire that feeds on labour", but instead of labour it "feeds on every aspect of every human's experience" (Zuboff 2019, 9). Zuboff employs certain quasi-Marxist categories but the core of her analysis could not be further from Marxism. She explicitly confirms this by claiming that existing categories, such as "monopoly" or "privacy" are inadequate to comprehend this "new economic logic" (Zuboff 2019, 14).

Let us take the example of the term "behavioural surplus" which heavily features in Zuboff's analysis and is reminiscent of "surplus value" especially when combined with the "new means of production", i.e. machine intelligence which renders this surplus. This term is central for Zuboff, as she claims that surveillance capitalism begins with the discovery of behavioural surplus (Zuboff 2019, 97). It is never explicitly defined, but it can be inferred as meaning that "more behavioural data are rendered than required for service improvements" (Zuboff 2019, 97). Zuboff claims that up until a certain point behavioural data were collected by digital corporations and put to work entirely on the user's behalf; she calls this the "behavioural value reinvestment cycle" (Zuboff 2019, 69). With the discovery of behavioural surplus, raw materials which until that point were solely used to improve the quality of search results were then put to use in the service of targeted advertising to individual users (Zuboff 2019, 74).

However, the term "behavioural surplus" has little analytical value as it does not explain the reasons for its discovery by surveillance capitalists or the antagonisms that its extraction entails, as we shall see in the following sections. For Marx, surplus value is the raison d'être of the capitalist mode of production; capitalism does not exist without the constant reproduction of conditions for surplus value extraction. Contrariwise, for Zuboff digital monopolies can somehow revert back to the "behavioural value reinvestment cycle" if they decide not to collect and render behavioural surplus and focus instead on use of data for service improvement. 
The core of Zuboff's argument is that "surveillance capitalism unilaterally claims human experience as free raw material for translation into behavioural data" (Zuboff $2019,8)$. This "behavioural surplus" is fed into the means of production of this new economic order, i.e. the advanced manufacturing processes known as "machine intelligence" (Zuboff 2019, 8; 95-96). The result of this process is "prediction products", which "anticipate what you will do now, soon, and later" and "are traded in a new kind of marketplace for behavioural predictions" called "behavioural futures markets" (Zuboff 2019, 8). Through the extraction and selling of behavioural data, surveillance capitalists are increasingly intervening "in the state of play in order to nudge, coax, tune, and herd behaviour toward profitable outcomes" (Zuboff 2019, 8).

The above contains very useful insights on the role of digitalisation in the processes of capitalist production and reproduction. For instance, the new capabilities presented by "machine intelligence" to deduce behaviour enabled targeted advertising (Zuboff 2019, 77-78), which revolutionises the process of realisation of surplus value. These insights could also be embedded in an analysis of the system of needs in capitalism and how the digitalisation process contributes to the distortion of this system for the purposes of realisation of surplus value. Last but not least, they could be used for a comprehensive analysis of the use of data in behaviour influence or modification towards systemic political solutions or in the process of de-politicisation, which is essential for the reproduction of capitalist social relations.

Nevertheless, Zuboff's analysis itself does not go very far with these insights precisely because her premise and, consequently, her conclusions are one-sided.

\subsection{A Break with Capitalism's Past...}

Let us take a closer look at Zuboff's theoretical premises, both of which stem from her claim that surveillance capitalism constitutes a break with capitalism's past. To begin with, there is an idealist foundation in her theoretical premise. This is manifest when she explicitly claims that "surveillance capitalism was invented by a specific group of human beings in a specific time and place" (Zuboff 2019, 85). She does this to argue that it is "not an inherent result of digital technology", nor "a necessary expression of information capitalism" (Zuboff 2019, 85). The implication of this claim is that "surveillance capitalism" results neither from the development of productive forces ("digital technology") nor from the development of relations of production ("information capitalism"), let alone from their contradiction; it rather results from the arbitrary, entirely contingent actions of a specific group of people in a particular time and place. This claim may be in line with postmodern approaches to historical development but it hardly contributes anything of value in the analysis of contemporary capitalist contradictions.

Arguably, the developments captured by Zuboff's concept of "surveillance capitalism" are the inherent result of the contradiction between forces and relations of production and how the latter determine the way in which the former are employed (even though there is always mutual determination). As we saw in Engels's contribution to the critique of political economy, the development of productive forces - including technological development - is never class neutral but always takes place in the context of specific relations of production that determine the aim, motivations, prioritisations and level of development of these forces. Instead of developing this further, Zuboff exhausts her analysis in superficial analogies that betray a lack of understanding of the logic of capitalism. Google's "revolution" of the twenty-first century is compared to Ford's "revolution" of the twentieth century. As Ford's inventions revolutionised production, "Google's inventions revolutionised extraction and established sur- 
veillance capitalism's first economic imperative: the extraction imperative" (Zuboff 2019, 87).

Additionally, Zuboff claims that surveillance capitalism inaugurates a new market form which "declares that serving the genuine needs of people is less lucrative, and therefore less important, than selling predictions of their behaviour" (Zuboff 2019, 93). In that way surveillance capitalism is opposed to a benevolent type of capitalism which supposedly serves the needs of society. Both of these claims are rather superficial. Capitalism as a whole is characterised by the logic and imperative of a specific kind of extraction, i.e. the extraction of surplus value which is the raison d'être of this mode of production, its existential precondition. As we shall see in the next section, is not "extraction"-in-the-abstract that is revolutionised by "surveillance capitalism" but, arguably, the extraction of surplus value from the user-consumer, as well as the processes of circulation and realisation of surplus value. After all, the thirst for profit determines the growth of data analysis and selling of prediction products to companies looking to actualise surplus value.

More importantly, the second claim is based on a misconception of the role of needs in capitalism. Zuboff expresses the view that needs-satisfaction is the causal root for healthy capitalist development and that "new market forms are most productive when they are shaped by an allegiance to the actual demands and mentalities of people" (Zuboff 2019, 32). Capitalism in general, she claims, "evolves in response to the needs of people in a time and place" (Zuboff 2019, 31). This again implies a distinction between a benign capitalism, represented by the Fordist model, and surveillance capitalism as its parasitic distortion. This distinction is also echoed in Zuboff's classification of big digital monopolies according to whether or not their operations respond to individual needs, or, as she puts it, whether they reunite supply and demand (Zuboff 2019, 30). In this context, Apple does not perform surveillance capitalism because it merely "collects behavioural data with permission and solely as a means to product or service improvement", whereas Amazon "appears to be migrating toward surveillance capitalism, with its new emphasis on 'personalized' services and third-party revenues" (Zuboff 2019, 22-23). In this way Apple represents a "new rational capitalism", which is part of a commercial reformation that shifts the focus of consumption from the mass to the individual (Zuboff 2019, 30).

Zuboff's superficial analysis allows her to side with one monopoly against another, completely disregarding the issue of exploitation, based on the argument that this new rational capitalism will better attune production to individual needs. However, the existence of a benign capitalism where production is focused on needs-satisfaction is refuted by the Marxian and Marxist analyses of capitalist contradictions. The needs of the people are not the causal root for capitalist development; profit is. In capitalist society, the satisfaction of social needs is not an end in itself. On the contrary, the end of production is the valorisation of capital, whereas the satisfaction of social needs (on the market) is only a means towards this end (Heller 2018, 49). As Marx puts it: "a certain rate of profit [...] determines the expansion or contraction of production, instead of the proportion between production and social needs, the needs of socially developed human beings" (Marx 1894, 367).

The opposition between a benign capitalism and a distorted capitalism, whose manifestation surveillance capitalism is, echoes the neo-Keynesian distinction between neoliberalism and welfare capitalism. The above points suggest that surveillance capitalism continues along the path of neoliberalism and exacerbates its worse tendencies. Indeed, Zuboff argues that surveillance capitalism departs from the history of market capitalism as it abandons the "reciprocities with people and society" and 
imposes a "totalising collectivist vision of life in the hive" (Zuboff 2019, 21). This constitutes a break with capitalism's past, where firms relied "on people as employees and customers" and where "price increases had to be balanced with wage increases": "surveillance capitalists no longer rely on people as consumers" (Zuboff 2019, 499). The "coup from above" that surveillance capitalism signifies is the destruction of the centuries' old social contract between capitalism and its communities.

\section{2. ...or Direct Result of Capitalist Contradictions?}

Two points need to be raised regarding Zuboff's idyllic representation of capitalism's past that follow from Engels's insights on the labour theory of value. First, her representation of the "social contract" between capitalism and its communities is not a very accurate depiction of capitalist reality. The relationship between capital and employees is not one of reciprocity but rather one mediated by the extraction of surplus value. The wage is neither a gift nor a gesture of social awareness by the capitalist to their employees. The wage represents the value of labour power, which is determined by the value of means of subsistence necessary to reproduce this labour power. The capitalist has an interest to pay a wage that corresponds to the bare necessities which will ensure the worker appears every day for work. It is only the collective struggle of the workers, based on the exact opposite interest, which can pressure capitalists into concessions and "reciprocities" to the working class.

Moreover, it has to be noted that the reproduction of capitalism does not primarily rely on consumers' demand, but rather on conditions of profitability which enable the expanded reproduction of capital. Capital sustains itself only on the basis of the iron law of accumulation. Capital needs to valorise itself and can only do this through the appropriation of more and more surplus value, through the exploitation of the living labour it employs. As long as conditions of profitability are ensured, its reproduction is also ensured; which is why the tendency of the rate of profit to fall poses the main barrier through which capital constantly tries to escape. On the contrary, consumers' demand may not be the determining factor for a capitalist crisis (as Keynesian approaches would argue), but it is an important factor that affects the development of such a crisis. Last but not least, it is important to note that surveillance capitalists may indeed "no longer rely on people as consumers", but they sell their products to companies that do. Digitalisation has revolutionised the process of circulation and realisation of surplus value, making it more efficient for capital. But in no way has this altered the main parameters of capitalist production, contrary to Zuboff's argument.

Zuboff's nostalgia for an idyllic capitalist past determines the prescriptive part of her exposition: capitalism, which is never meant to be eaten raw, is to be "cooked" with democracy and regulation. Hence, her insistence on the need for new laws: regulation of the raw aspects of surveillance capitalism, similar to the regulation of the "antisocial and antidemocratic practices of raw industrial capitalism" is the solution (Zuboff 2019, 343). A new wave of "progressive" legislation, reminiscent of the welfare reforms that once righted "the balance of power between employers and workers" is necessary to reject "the fundamental legitimacy of surveillance capitalism's declarations and interrupt its most basic operations, including the illegitimate rendition of human experience as behavioural data" (Zuboff 2019, 343).

It is evident from the above that Zuboff's prescription follows directly from the premises of her analysis. Her diagnosis that surveillance capitalism constitutes a break with capitalism's past leads to the conclusion that we can return to this idyllic past through reform. Thus, her prescription consists of a systemic proposal to mitigate the effects of what she calls "surveillance capitalism", rather than eradicate the 
problem by radically changing the orientation and use of the relevant technologies. She argues for a return to a capitalism that tends to people's needs by reuniting supply and demand. Echoing this fundamental concern of neo-Keynesians Zuboff betrays a theoretical misconception of capitalist contradictions and the role of technological development in their unravelling.

We argue instead that surveillance capitalism is the direct result of developing contradictions inherent in the capitalist mode of production. Phenomena like data mining and targeted advertising revolutionise the processes of circulation and realisation of surplus value; the radical increase in the velocity of the former leads to a radical reduction of the turnover time and, thus, operates as a factor that counters the LFRP, i.e. the ultimate barrier of the capitalist mode of production. As a direct result of capitalist contradictions, surveillance capitalism cannot be reformed; productive forces cannot be put to different use or employed to satisfy social needs, unless embedded in a different system of productive forces and social relations.

\section{Marxist Critiques of Digital Surveillance}

Let us develop these points further by looking at alternative views on digital surveillance in order to show how they contribute to more comprehensive analyses of phenomena and processes described as "surveillance capitalism" by Zuboff, as well as how Engels's analysis has influenced and can further influence these approaches. These contributions focus on the economic implications of internet surveillance (Fuchs et al. 2012, Andrejevic 2013), as well as several other aspects of the process of digitalisation (Fuchs and Sandoval 2014; Fuchs and Mosco 2016) from a Marxist perspective. Central to these approaches is the focus on the totality of capitalist social relations, while ascribing primacy to the relations of production and the issue of exploitation. The relations of distribution and circulation are assessed in their unity with the relations of production, in accord with the methodological principles developed by Marx and Engels's critique of the capitalist economy (Marx 1857-1858, 83111).

Based on the main principles of the labour theory of value, these analyses conclude that surveillance is intrinsic to the capitalist mode of production and the process of capital accumulation. Marx distinguishes two spheres of capital accumulation: the circulation sphere and the sphere of production (Fuchs 2012, 39). In the circulation sphere, capital first appears in the form of money and transforms itself into commodities: the capitalist buys the commodities of labour power and means of production (Marx 1885, 116). In the sphere of production, new goods are produced embodying the value of labour power (in the form of variable capital) and the value of the means of production (in the form of constant capital).

Surveillance is a central means to various ends in both spheres of the process of capital accumulation. Capital employs different methods of surveillance in the processes of production and circulation in order to minimise the risk of incurring losses and maximise the opportunities for making profits (Fuchs 2012, 43). For instance in the sphere of production, surveillance targets the workers at the workplace through managers, supervisors, workplace surveillance technologies, databases, participatory management, identification systems, surveillance of employees' Internet activities, etc. (Fuchs 2012, 45). Marx himself had identified the significance of surveillance practices "from the moment that the labour under capital's control becomes cooperative" (Marx 1867, 449). According to Marx, the supervision of labour in the production process is "purely despotic": the industrial army of the workers "under the command of a capitalist requires, like a real army, officers (managers) and N.C.O.s 
(foremen, overseers), who command during the labour process in the name of capital" (Marx 1867, 450).

Similarly, in the sphere of circulation the target of surveillance can be the potential workforce, i.e. the applicants for employment, which a corporation scrutinises through access to criminal records, health databases, bank data, employment histories, information search on the Internet, etc. (Fuchs 2012, 45). More relevant to our discussion, surveillance in the sphere of circulation takes the form of consumer surveillance, whereby "consumption interests and processes are systematically observed and analyzed in order to guarantee the selling of as much commodities as possible and the realization of profit" (Fuchs 2012, 45). This used to take place through marketing and consumer research, but it now predominantly takes place through digital surveillance mechanisms, i.e. cookies, targeted advertising mechanisms, spyware, profiling of Internet usage behaviour, data mining, clickstream monitoring, etc. (Fuchs 2012, 45).

The primacy ascribed by this Marxist approach to the relations of production has led to the appearance of literature which explores the issue of exploitation in the process of surveillance and data collection. A critique of digital surveillance from this angle goes beyond the one-sidedness of the critique of privacy invasion. It is argued that the latter "does not do justice to the productive character of consumer surveillance", whereby consumers are asked to pay for surplus extracted from their own work (Andrejevic 2012, 73). Under this prism, the crucial question is if the users of commercial social media are generating value and whether they are exploited (Fuchs $2016,45)$. This question leads to an exploration of several other questions: Is platform usage creating value (i.e. time objectified in a product sold as a commodity)? What activity counts as labour? Is the sole criterion value creation? Even if such activity is contributing to value creation, is this activity productive labour? Is there a relation of exploitation? Is there coercion and alienation and where are they located?

The answers to these questions are far from settled, but a compelling attempt to answer them can be found in Christian Fuchs's elaboration that is based on a conception of productive labour as labour of the collective worker. This concept is set out by Marx in Capital: "In order to work productively, it is no longer necessary for the individual himself to put his hand to the object; it is sufficient for him to be an organ of the collective labourer, and to perform any one of its subordinate functions" (Marx $1867,643-644)$. Fuchs goes on to define what he calls the symbolic value of a commodity, i.e. a cultural component that is created by cultural labour, which "establishes a link and mediates between use-value and exchange-value", by helping convince potential buyers that a good or service will enhance their lives thereby contributing to the completion of the exchange, in which consumers obtain use-values and capitalists realise their profit (Fuchs 2016, 51). Fuchs argues that the labour-time invested in the creation of this symbolic dimension (through departments of public relations and advertising) is calculated into the price of commodities

Turning to the commodities produced by social media corporations, he argues that they consist of a portion/space of a user's screen/profile that is filled with ad clients' commodity ideologies, highly targeted to user activities and interests (Fuchs $2016,53)$. For the creation of this commodity, the users' constant online activity is necessary "for running the targeting algorithms and for generating viewing possibilities and attention for ads": "the ad space can therefore only exist based on user activities that are the labour that create the social media prosumer commodity" (Fuchs $2016,53)$. Once he concludes that platform usage is labour, Fuchs goes on to argue that it is also productive labour by providing an analogy with transportation labour. In 
the same way that the labour in the transportation industry adds value to the products transported, "partly through the value carried over from the means of transport, partly through the value added by the work of transport" (Marx 1885, 226-227), advertising transport workers transfer value on the product by organising "a communication space that allows advertisers to communicate their use-value promises to potential customers" (Fuchs 2016, 54). Therefore, platform users create value, as their labour is objectified in these commodities, and usage of these platforms is productive labour. Users are productive workers whose activities are necessary for "transporting" use-value promises from companies to potential customers: in the twenty first century transportation labour is communication labour (Fuchs 2016, 54).

This is arguably a compelling application of the labour theory of value, developed by Marx and Engels, to the analysis of contemporary processes and phenomena. It is certainly a more comprehensive and many-sided account of the processes and phenomena captured by the term "surveillance capitalism" than the one offered by Zuboff, because it places emphasis on capitalist relations of production and circulation that Zuboff fails to address - from the standpoint of surplus-value realisation and profitability. It therefore assesses the growth of social media platforms as a response to capitalist contradictions that is in line with capital's thirst for profit and permanent need for expanded reproduction and not as an aberration of a system that normally corresponds to social needs.

With regards to the process of circulation, the Marxist approach to digital capitalism builds on the aforementioned contradiction, identified by Engels, between "the enormous expansive force of industry" and the resistance offered "by consumption, by sales, by the markets for the products of modern industry" (Engels 1880, 315). It is argued that the advancement of information and communication technologies corresponds to the need to overcome the barrier of consumption. Digital platforms and new media are crucial for the articulation of the consumption capacity of individuals. The new digital information and communication technologies reproduce a social being whose capacities develop in line with the requirements of circulation (Manzerolle and Kjøsen 2016, 169). For instance, through the advancement of such technologies free time is mobilised to serve the circulatory needs of capital: "the colonisation of everyday life by digital and networked devices has opened up new pores, cracks, and crevices of daily life into possible moments of communicative utility in service of capital's logic of acceleration" (Manzerolle and Kjøsen 2016, 169).

The above is directly relevant to the contradiction between production and consumption, however, the issue of profitability is not explored. This is where Engels's discussion on capital's turnover time is crucial. Christian Fuchs hints at this when he refers to turnover time as the sum of the circulation time and production time (Fuchs 2016, 40), but it is Manzerolle and Kjøsen who come closer when they discuss the role of new media platforms in radically increasing the velocity of capital and consequently decreasing the time of circulation: "to accelerate [...] capital must develop or adopt media that allows it to bind space and time, and thereby progressively overcome the barriers capital posits to its functioning" (Manzerolle and Kjøsen 2016, 158). This increase of velocity is approached from the perspective of surplus value creation: because the sum and mass of surplus value created within a period is negatively determined by the velocity of capital, the faster capital moves through the sphere of circulation, the more surplus value will be created and validated (Manzerolle and Kjøsen 2016, 159).

However, as we saw in the first section, Engels showed that any factor which affects the production of surplus value by influencing the turnover time of capital also 
affects the rate of profit. Reducing the time of circulation equals reduction of turnover time, equals increase of the rate of profit. As Engels put it, "the chief means of "cutting circulation time has been improved communications" (Marx 1894, 164). This is what directly links the process of digitalisation and phenomena described as surveillance capitalism to the LFRP. The effect of the reduction of circulation time, enabled by data capture and data mining as well as targeted advertising, on the rate of profit is key to explain the growth of new media platforms, because it points to the central contradiction in capitalism, i.e. the tendency of the rate of profit to fall.

This ultimate barrier to the capitalist mode of production is countered by many factors, some of which are mentioned by Marx and Engels in Volume three of Capital. Recently it was argued that the exponential growth of the banking and finance sector should be regarded as a further (temporary) countertendency to the LFRP (Passarella and Baron 2015). This sector enables industrial firms to increase the speed of turnover of their capital, therefore crucially affecting their profitability. I argue that the above practices (e.g. data mining, targeted ads, etc.), captured under the terms "surveillance capitalism" or "digital capitalism" can also be considered among the factors that counter the LFRP. Consequently, not only the process of "financialisation" of advanced economies but also the process of "digitalisation" of the last decades can be considered as the "humpback bridge" that the capitalist class has eventually gone through to sustain the profitability of capital (Passarella and Baron 2015).

\section{Conclusion}

This paper tentatively but explicitly articulated the hypothesis that Engels's elaboration on the effect of capital's turnover time on profitability provides an analytical framework within which the growth of digital media platforms and phenomena like targeted advertising can be explained. It follows that the exponential growth of digital platforms can be explained as a direct result of the development of capitalist contradictions, especially the contradiction between productive forces and relations of production as expressed in the LFRP. On this basis, Shoshana Zuboff's claim that surveillance capitalism constitutes a radical break with capitalism's past was countered.

Marxist contributions to the critique of digital surveillance have already approached this phenomenon in a many-sided manner. Rather than focusing solely on the issues of privacy or wealth, they have explored whether the growth of digital surveillance can be attributed to developments in productive relations, relations of circulation from the standpoint consumption, i.e. surplus value realisation, as well as relations of circulation from the standpoint of surplus value production. This paper built upon these contributions and suggested approaching this phenomenon with a focus on the process of circulation from the standpoint of profitability. Ultimately, this paper seeks to invite further research on this issue, as well as stress that Engels's work remains absolutely relevant for the analysis of the contradictions of contemporary capitalist societies.

\section{References}

Althusser, Louis. 2006. For Marx. London: Verso.

Anderson, Kevin. 1995. Lenin, Hegel, and Western Marxism: A Critical Study. Chicago: University of Illinois Press.

Andrejevic, Mark. 2013. Infoglut: How Too Much Information Is Changing the Way We Think and Know. London: Routledge. 
Andrejevic, Mark. 2012. Exploitation in the Data Mine. In Internet and Surveillance: The Challenges of Web 2.0 and Social Media, edited by Christian Fuchs, Kees Boersma, Anders Albrechtslund, and Marisol Sandoval. 71-88. London: Routledge.

Carchedi, Guglielmo and Michael Roberts. eds. 2018. World in Crisis: A Global Analysis of Marx's Law of Profitability. London: Haymarket Books.

Carver, Terrell. 1984. Marxism as Method. In After Marx, edited by Terrence Ball and James Farr. 261-278. Cambridge: Cambridge University Press.

Engels, Friedrich. 1880. Socialism: Utopian and Scientific. In Marx \& Engels Collected Works (MECW) Volume 24, 281-325. London: Lawrence \& Wishart.

Engels, Friedrich. 1878. Anti-Dühring. Herr Eugen Dühring's Revolution in Science. In Marx \& Engels Collected Works (MECW) Volume 25, 5-309. London: Lawrence \& Wishart.

Foster, John Bellamy. 2017. The Return of Engels. Monthly Review 68 (10).

Fuchs, Christian. 2016. Towards Marxian Internet Studdies. In Marx in the Age of Digital Capitalism, edited by Christian Fuchs and Vincent Mosco. 22-67. Leiden: Brill.

Fuchs, Christian. 2012. Critique of the Political Economy of Web 2.0 Surveillance. In Internet and Surveillance: The Challenges of Web 2.0 and Social Media. edited by Christian Fuchs, Kees Boersma, Anders Albrechtslund and Marisol Sandoval. 31-70. London: Routledge.

Fuchs, Christian, Kees Boersma, Anders Albrechtslund and Marisol Sandoval. eds. 2012. Internet and Surveillance: The Challenges of Web 2.0 and Social Media. London: Routledge.

Fuchs, Christian and Vincent Mosco. eds. 2016. Marx in the Age of Digital Capitalism. Leiden: Brill.

Fuchs, Christian and Marisol Sandoval. eds. 2014. Critique, Social Media and the Information Society. London: Routledge.

Gould, Stephen Jay. 1977. Ever Since Darwin. New York: Norton.

Heinrich, Michael. 2016. "Capital" after MEGA: Discontinuities, Interruptions and New Beginning. Crisis and Critique 3 (3): 93-138.

Heinrich, Michael. 2013. Crisis Theory, the Law of the Tendency of the Profit Rate to Fall, and Marx's Studies in the 1870s. Monthly Review 64 (11).

Heinrich, Michael. 1996/97. Engels's Edition of the Third Volume of Capital and Marx's Original Manuscript. Science and Society 60 (4): 452-466.

Heller, Agnes. 2018. The Theory of Need in Marx. London: Verso.

llyenkov, Evald. 2020. Intelligent Materialism: Essays on Hegel and Dialectics. Chicago: Haymarket Books.

Lewontin, Richard and Richard Levins. 1985. The Dialectical Biologist. Cambridge, MA: Harvard University Press.

Losurdo, Domenico. 2004. Hegel and the Freedom of the Moderns. Durham, NC: Duke University Press.

Manzerolle, Vincent and Atle Mikkola Kjøsen. 2016. Digital Media and Capital's Logic of Acceleration. In Marx in the Age of Digital Capitalism, edited by Christian Fuchs and Vincent Mosco. 151-179. Leiden: Brill.

Marx, Karl. 1894. Capital. Volume III. London: Penguin.

Marx, Karl. 1885. Capital. Volume II. London: Penguin.

Marx, Karl. 1868. Letter to Engels, April 30. In Marx \& Engels Collected Works (MECW) Volume 43, 20-25. London: Lawrence \& Wishart.

Marx, Karl. 1867. Capital. Volume I. London: Penguin.

Marx, Karl. 1857/1858. Grundrisse: Foundations of the Critique of Political Economy. London: Penguin.

Mavroudeas, Stavros. 2020. Friedrich Engels and his Contribution to Marxism. Human Geography 13 (2): 187-190.

McLellan, David. 1977. Friedrich Engels. Harmondsworth: Penguin. 
Moseley, Fred. 2018. The Development of Marx's Theory of the Falling Rate of Profit in the. In Marx's Capital: An Unfinishable Project?, edited by Marcel Van der Linden and Gerald Hubmann. 95-143. Leiden: Brill.

Moseley, Fred. 2015. Introduction. In Marx's Economic Manuscript of 1864-1865. edited by Fred Moseley. 1-44. Leiden: Brill.

Passarella, Marco Veronese and Hervé Baron. 2015. Capital's Humpback Bridge: "Financialisation" and the Rate of Turnover in Marx's Economic Theory. Cambridge Journal of Economics 39 (5): 1415-1441.

Roberts, Michael. 2015. The Marxist Theory of Economic Crises in Capitalism - Part One. Retrieved from https://thenextrecession.wordpress.com/2015/12/27/the-marxist-theory-ofeconomic-crises-in-capitalism-part-one/

Roberts, Michael. 2013. Michael Heinrich, Marx's Law and Crisis Theory. Retrieved from https://thenextrecession.wordpress.com/2013/05/19/michael-heinrich-marxs-law-andcrisis-theory/

Roth, Regina and Fred Moseley. 2002. Guest Editors' Introduction. Journal of Political Economy $32(1): 3-13$.

Seigel, Jerrold. 1978. Marx's Fate: The Shape of a Life. Princeton: Princeton University Press.

Waitzkin, Howard. 1983. The Second Sickness. New York: Free Press.

Zuboff, Shoshana. 2019. The Age of Surveillance Capitalism: the Fight for a Human Future and the New Frontier of Power. London: Profile Books.

\section{About the Author}

Dimitrios Kivotidis

Dr. Dimitrios Kivotidis is Lecturer in Law at the University of East London. His research focuses on legal and political theory, constitutional law and human rights, as well as on the relationship between law and political economy. He is a member of the editorial collective of Legal Form, a forum for Marxist analyses of law. 